ELK

Asia Pacific Journals

www.elkjournals.com

\title{
"PROSPECTS AND PROBLEMS OF INDIAN POSTAL SYSTEM- A STUDY WITH SPECIAL REFERENCE TO SHIMOGA TOWN"A STUDY
}

\author{
Manjula Bai H \\ Faculty Member \\ Dept of Post Graduate Studies and Research in Commerce \\ Kuvempu University \\ Shankaraghatta \\ manjularaikar76@gmail.com \\ $\mathrm{Ph}: 9886219292$
}

\begin{abstract}
The present paper provides a platform to understand the prospects and problems of Indian postal system with special reference to Shimoga town. So in order to collect this information, a researcher has selected 100 responents who have opened an account with the post office in Shimoga branch. It particularly focused on the problems or the benefits availed from the post office services provided by Post office. Most of the people are not fully aware about the various post office schemes and most of the people are investing their money in banks and LIC's instead of post offices. This cause reduction of deposit at the post office. So there is a need to give proper advertisement about the various services and schemes of the post office. So this study deals to overcome those problems and finding a suitable suggestion on that, to overcome them. All levels of customers were surveyed by using questionnaire and the level of satisfaction or dissatisfaction from the postal services was studied. Finally the detail information about the benefits they had received were also considered. An attempt has been made to offer suggestions to post office to improvise their services.
\end{abstract}

\subsection{INTRODUCTION}

The post office is universally recognized as a facilitator of communication. It has been backbone of country's socio-economic development. Post office has become a big business Icon in corporate world. It touches the lives of Indian citizen in many ways; Delivering mail, E-post, E-billing, Retail post, Media post, Mutual Fund, Western Money Transfer, Business post, Express Post, accepting deposit under small saving scheme, providing life insurance and Rural Postal Life Insurance and providing retail 
ISSN 2349-2325 (Online); DOI: 10.16962/EAPJFRM/issn. 2349-2325/2015; Volume 9 Issue 4 (2018)

services like bill collection, sale of forms etc. The Department of post also act as agent for Government of India in discharging other services for citizens.

The post office provides postal and non-postal services. For more than 150 years post office has been the backbone of the country. India possesses the largest network of postal offices. Post offices have traditionally acted as vital channel for small household savings. The Department of post, trading as India Post, is a government postal system in India. It is generally referred as India Post. As on $31^{\text {st }}$ March 2011 the Indian postal services and planning had $1,54,866$ post office of which $1,39,040$ were in rural areas and 15,826 in urban areas.

The financial services offered by post offices are saving schemes, postal life insurance, rural postal life insurance. The post office small savings scheme provides a secure, risk free, attractive, investment option for small investment and offers the saving products across 1,55,000 post offices. POSB are the oldest savings bank in India and the largest in banking system.

Lord Clive first established the postal system in country in 1766 . Later on Warren Hasting developed the system by establishing Calcutta Grand Post Office (GPO) under a post master general in 1774.
In other presidencies of Madras and Bombay, it came into existence in 1786 and 1793. The Act of 1834 first regulated the post office on a uniform basis to unit the organization throughout the three presidencies into one All India Service. The Post Office Service Act 1854, however, reformed the entire fabric of the postal system with placing the post offices of India on the present administrative footing on October 1854.

The Indian Postal Service has $1,55,333$ post offices of which $1,39,040$ $(89.78 \%)$ are in rural areas and 15,826 $(10.22 \%)$ are in urban areas. It has 26,464 departmental post offices and 1,29,402 BPOs. At the time of independence, there were 23,344 post offices, which were primarily in urban area. Thus registered a sevenfold growth since independence with the focus of the expansion primarily in rural area. India Post provides various services depending on customer requirement to extend the benefits of its huge network in the area of communication services.

The postal network of over 1,55,000 outlets is the largest network in the World and also arguably the largest retail network in the country. It's capacity to handle financial transaction the intimate knowledge of the environment in any part of the country. In this era of economic liberalization, the post office is gearing 
ISSN 2349-2325 (Online); DOI: 10.16962/EAPJFRM/issn. 2349-2325/2015; Volume 9 Issue 4 (2018)

itself to meets its social obligations as well

as the challenges of the commercial, competitive environment and business world.

\subsection{REVIEW OF LITERATURE}

Ritika Aggarwal (2012) made a study on "Identifying Factor Infuencing Preference towards Post Office Savings

Scheme" argues that,

India is one of rapidly growing economies of Asia. India post office savings bank is widely known and traditional formal institution offering saving products. Globalization has brought outsized revolution in the financial sector of the Country, which proves to be challenging for post office SB's. Liberalization has substantially increased better and innovative investment possibilities to the investor, and it is also including several scheme. The post office savings bank is the oldest and largest banking institution in the country.

- Ms.N. Kalaiarasi and Ms. S saranyadevi (2016) made a study on

"DepositorsSatisfaction And Level of Awareness Towards Post Office Savings Bank Schemes with Special
Reference To Udumalpet ${ }^{\text {“ }}$

Explain that,

People have a tendency of saving out of their income to secure their future as can not be predicted. Post Office Savings Schemes play an important role in the development of economy as it offers an opportunity for the poor people. The primary objective of the study is to find out the extent of satisfaction among the depositors of post office savings scheme. The study revealed that all the depositors were aware of the savings account, Monthly income scheme, Time deposit account, senior citizen savings scheme and recurring deposit account. It is identifying the awareness of respondents about the various savings scheme offered by post office.

- D Sivasakthi and S Gandhimathi (2016) make a study on "A Study An Investor's Attitude Towards Post Office Savings Schemes in Chinniampalayam" argues that,

Post Office Savings Scheme provides a secure, risk free and attractive investment option for the small investors. Investment culture refers to the attitudes, perceptions, and willingness of individuals, and institutions in placing their savings in various financial assets more popularly 
ISSN 2349-2325 (Online); DOI: 10.16962/EAPJFRM/issn. 2349-2325/2015; Volume 9 Issue 4 (2018)

known as investment or Postal Savings. Its

regulation of savings in general and

protection and promotion of small and house-hold investors in particular and regulatory authorities to understand the investors perceptions and their preferences. Thus collected has been classified, edited and tabulated for analysis. It is best scheme, all people belonging to different occupation use postal services. Both literate and illiterate people use the postal service.

\section{G.velmurugan , V. Selvam and N . Abdul} Nazar (2015) make a study on "An Empirical Analysis on Perception of Investors Towards Various Investment Avenues" Explain that,

Financial markets play a vital role in the economic development of a country. The economic liberalization and globalization have brought a fervent environment for the common and small investors who are willing to participate in the various investment avenues available in India. There are large number of small investors. Who have the ability to save and make an investment in share market, gold, real estate, insurance and post office. A survey on investment literature of equity, insurance and mutual fund perspective and perception of women investors towards investment avenues in India. Find out the perception of investors relating to safety, liquidity, and high returns dimensions and improve the economic development.

\section{- B. Saranya and G. B Karthikeyan} (2015) make a study on "Preferences and Level of Satisfaction Towards Post Office Savings Scheme ( with special reference to coimbatore city )" opinion that,

Investment culture among the people of a country is an essential prerequisite for capital formation and the faster growth of an economy. Savings is common to all human societies, even if saving practices differ from one to another. In India there are multiple investment avenues available to meet differing needs of investor, greatly influenced by 3 factors viz., to meet the emergency needs, to meet the family needs in the near future. And to take care the well being of the children. If people get good services and good return during their investment tenure, It has become all the more important to study and analyse the investors, awareness, perceptions and preference behaviour of various investment avenues available to them in the market.

- Kore ShashikantD and Dr. R.B Teli(2015) make a study 
ISSN 2349-2325 (Online); DOI: 10.16962/EAPJFRM/issn. 2349-2325/2015; Volume 9 Issue 4 (2018)

on " Investment behaviour of

postal customers towards post office savings bank scheme : a case study of Kolhapur district ( M.S ) opinion that ,

Presently in India, there are various investment schemes and opportunities are available for an individual to his savings and the appropriate investment scheme opportunities provided by many financial institution like commercial and cooperative banks, Indian post, LIC etc. There are several type of POSB schemes that later to the differing needs of various classes of people in which they have and option to invest with very small amount most of the postal investment is exempted from Income Tax Act 1961. Small and Medium investors have a great faith very clear perception and positive approach towards POSB scheme and strong support to the union government.

- Dr.Dhiraj Jain and Ms. Ruhika Kothari make a study on "Investors Attitude Towards Post Office Deposits Schemes - Empirical study in Udaipur district, Rajastan". Stated that,

The investment avenues provided by the post offices are generally marketable as they are a savings media. For more than 150 years, Department of posts has been the backbone of the country's communication and has played a vital role to connect the whole country. Person has an option to invest even a minimum amount of ₹500 per month, maximum ₹ $1,10,000$ per financial year is totally exempt from tax U/S 10 of IT Act 1961. Interest also exempted. The study is an attempt to identify the awareness, preference, problem and attitude of investors. The board consists of a chairman and 6 members. The 6 members are Board hold portfolios of personnel, operations, Technology, Postal Life Insurance, HBDand planning functions, majority of the respondents were aware about post office deposits scheme through friends, relatives and agents.

\subsection{OBJECTIVES OF THE STUDY}

- To study the overall performance of post office in the Shimoga town.

- To study the various services offered by the post office in the Shimoga town

- To know the preference of the customer for different post office saving schemes offered by the branch.

- To study the customer opinion regarding tax benefits and returns from the post office deposit scheme. 
ISSN 2349-2325 (Online); DOI: 10.16962/EAPJFRM/issn. 2349-2325/2015; Volume 9 Issue 4 (2018)

- To examine the problem faced by depositors in post office deposit schemes.

- To study the contribution made by the post office towards the development of the economy.

- To identify the awareness of respondents about the various savings scheme offered by post office.

- To study the preference of the investors for different post office savings options.

- To find out the factors that influence investors to invest among post office saving products.

- To study about the level of satisfaction of the investors.

- To understand the effect of demographic factors affecting the choice of investment.

- To study the investor's opinion regarding tax benefit and returns from post office deposits schemes.

- To study the various POSB schemes of Indian post.

\subsection{STATEMENT OF THE PROBLEM}

The post office has been the backbone of the country's communication and plays a vital role to connect the whole country. It has touched the lives of every citizen through mail, banking, insurance, money transfer and retail services like bills collection sales of forms etc. But most of the people are not fully aware about the various post office schemes and most of the people are going to invest their money in banks and LIC's instead of post offices. This cause reduction of deposit at the post office. So there is a need to give proper advertisement about the various services and schemes of the post office. So this study deals to overcome those problems and findings a suitable suggestion on that to overcome them.

\subsection{SCOPE OF THE STUDY}

Scope of the study mainly confined to Shimoga town. There are many branches in Shimoga town and also provided good infrastructure facility, good service, large number of the public interest and also large network. The scope involves various services offered by post office in Shimoga town and it's branches.

\subsection{REASEARCH METHODOLOGY}

\section{Sources of data}

For the purpose of the study, data is collected from two ways one is primary data and another one is secondary data.

\section{- Primary data}

It refers to first-hand information. It is collected directly from the field of research through the investigation in the form of 
ISSN 2349-2325 (Online); DOI: 10.16962/EAPJFRM/issn. 2349-2325/2015; Volume 9 Issue 4 (2018)

questionnaire, with multiple options and one open ended question. This included more of inter personnel interaction and enlisting their responses and recording their statements .And also it included distributing a structured questionnaire to the respondents who owned account in post office.

\section{- Secondary data}

Secondary data are those which have already been collected by someone else and which have already been passed through the statistical process. These are collected by books, records and relevant data has been collected from direct website.

\section{> Sample Design}

The sample respondents were selected from the post office of Shimoga town. A sample of 100 respondents was taken for collection of data required for study on the basis of random sampling.

\section{$>$ Statistical tools and techniques}

For the purpose of analysing the collected information from the respondents, the statistical tools and techniques are used i.e. table, charts and graphs and Chi square test. Presentation of the data is to make projections and to draw meaningful conclusion.

\subsection{LIMITATIONS OF THE STUDY}

- Lack of response by the respondents
- Time constraints

- The survey is conducted only few respondents of post office of Shimoga town.

- The present study is limited only to Shimoga town.

- It is a micro level of study, therefore for the findings of the study are applicable only to branches in Shimoga town.

\subsection{PRODUCTS AND SERVICES OF POST OFFICE}

\section{Premium products}

The business development and marketing directorate manages and markets all the premium products like :-

1. Speed post

2. Business post

3. Express parcel post

4. Media post

5. Greeting post

6. Logistics post.

- Services

$>$ Postal services

1. Speed post

2. E-payment

3. Logistic post

4. E-post

5. Business post

6. Media post 
ISSN 2349-2325 (Online); DOI: 10.16962/EAPJFRM/issn. 2349-2325/2015; Volume 9 Issue 4 (2018)

7. Direct post

8. Postal Life Insurance

9. Instant money order services (IMO)

10. International Money Transfer

$>$ Non-Postal services

The post office has also traditionally served as a financial institution for millions of people in rural India. Currently these are some of the activities being supported:

1. Public Provident Fund (PPF)

2. National Savings Certificate (NSC)

3. Kisan Vikas Patra

4. Savings Bank Account

5. Monthly Income Scheme

6. Recurring Deposit Account

7. Nationals Savings Scheme 1992

8. Post Office Time Deposit

9. Post boxes for mail receipt

\subsection{NEW PRODUCTS AND SERVICES BY DEPARTMENT OF POSTS.}

\section{1. .Electronics fund transfer}

\section{Warrant Payment}

\section{Electronic clearance service (ECS)}

4. Sukanya Samridhi Scheme Under the scheme parents and legal guardians can open accounts in the name of two girls children up to 10 years of age. The minimum investment is Rs.1000 a year.
5. The Ponmangan Podhuvaippu Nidhi:

The Ponmangan Podhuvaippu Nidhi can be opened any time before the boy child attain the age of 10 years.

From the below table it can be interpreted that (Ref Table- 1)

1. Majority of the persons who have an account in post office are male (52\%), but women also have a major share because all type of small savings are being made by women's.

2. People of the age group (21-40) have opened a postoffice account, $(40 \%)$ as they are youngsters and have consideration for saving in the future. Even the age group (40-61) have also opened the account, $(36 \%)$ to save for their future.

3. Most of the account holders are agriculturist and students who have a small portion of savings.

From the above table it clearly shows that out of the 100 respondents $42 \%$ of the respondents are expected to invest in monthly saving scheme (PORD), 16\% of the respondents are expected to invest in quarterly income earning scheme, $28 \%$ of the respondents are expected to invest in monthly income earning scheme and rest of 
ISSN 2349-2325 (Online); DOI: 10.16962/EAPJFRM/issn. 2349-2325/2015; Volume 9 Issue 4 (2018)

the $14 \%$ of the respondents are expected to tax benefit scheme basis. (Ref Table- 2)

It is interpreted that majority of the post office customers are interested to invest in monthly savings scheme (PORD) because, it yields interest on monthly basis because, and majority of the customers investing are agriculturist.

From the above table it shows that out of the 100 respondents $10 \%$ of the respondents are prefer the post office savings scheme because, it is attractive, $60 \%$ of the respondents prefers the post office savings scheme for savings, $22 \%$ of respondents prefer the post office savings scheme for tax benefit and rest of the $8 \%$ respondents prefer post office saving scheme for liquidity. (Ref Table- 3)

It is interpreted that majority of the customer prefer the post office for saving purpose because, majority of the people are agriculturist and students. So they want to save more money for their future life.

From the above table it clearly show that only 2 responses are towards excellent in post office services, 37 responses are towards very good in services, 117 responses are towards good in services, 82 responses are towards average in services, 11 response are towards poor in services. (Ref Table- 4)

It is interpreted that majority of the respondents where satisfied with the services given by the workers of the post office and majority of the respondents opinion are good and average point of view.

From the above table it clearly shows that 5 responses are towards excellent in non postal services, 53 response are toward very good in Non-postal services, 173 responses are towards good in non-postal services, 100 responses are towards average in nonpostal services 20 responses are towards poor in non-postal services. (Ref Table- 5)

It is interpreted that majority of respondents opined that post office saving account is good because, interest in saving account is tax free or tax benefit, but excellent perform is low because now a days government is providing other savings scheme .

From the above table it clearly shows that 161 responses are aware about the above services and 139 responses are not aware about the above services. (Ref Table- 6)

It is interpreted that majority of the respondents use speed post and aware about 
ISSN 2349-2325 (Online); DOI: 10.16962/EAPJFRM/issn. 2349-2325/2015; Volume 9 Issue 4 (2018)

all services because of its speed deliver services.

From the above table out of 100 respondents 40 respondents have opened a Sukanya Samrdhi scheme and remaining 60 respondents have not opened this scheme.

\section{(Ref Table- 7)}

It is interpreted that majority of the people are not opening this scheme, because this account is only for girl child parents.

From the above table it is shows that out of the 100 respondents $18 \%$ of the respondents say the post office should be privatize and $82 \%$ of the respondents say that it should not be privatized. (Ref Table- 8)

It is interpreted that majority of the respondents opined that post office should not be privatize because, majority of the respondents are satisfied with the service provided by the post office at present.

\section{Test Application}

Chi square Test

Degree of freedom n-1 i.e 2-1=1

Table value of chi square for 1 degree of freedom @ 5\% level of significance is

\subsection{1}

Since the calculated value is more than the table value, Null hypothesis is rejected.Hence alternative hypothesis is accepted .Hence proved that customers are satisfied with the CRM provided by post office, (Ref Table- 9)

\section{FINDINGS}

- From the analysis it shows that all the respondents have the habit of saving in post office.

- It shows majority of the respondents have open Saving Bank Account because, this was safest way to make a transactions.

- Majority of the respondents save $5 \%$ to $10 \%$ of their annual income in post office.

- It shows that majority of the respondents who have open account are agriculturist and students.

- When compared to banks and other institutions in post office is heavy work load for the employees.

- It is observed that in the post office provide specific scheme for girls like Sukanya Samrdhi Scheme.

- In post office there is nonavailability of loan facility to the account holders.

- Respondents opined that rate of interest given by post office is good because, Interest charged by post 
ISSN 2349-2325 (Online); DOI: 10.16962/EAPJFRM/issn. 2349-2325/2015; Volume 9 Issue 4 (2018)

office is very less when compared to

banks and other institutions.

- $60 \%$ of the respondents prefer medium term saving scheme because of medium risk and returns.

- Majority of the respondents are interested to invest in monthly saving scheme because, the small business people are having very less turnover and their earnings also less.

- Investment made by the respondents lies below 5000 because, majority of the respondents are students and their income is mainly depend on their parents income.

- Majority of the respondents prefer post office for their saving purpose.

- Majority of the respondents are aware about Postal and Non-Postal services.

- Majority of the respondents are aware about the services like as Speed post, Business Post, Direct post etc.

\section{SUGGESTIONS}

- The post office should provide a loan facility to the customer so that loan sanction date should be according to customer convenient and also provide more period for repayment of loan charged at low rate of interest.

- It should provide more employees opportunities to meet the excess work load reduce job stress among employees.

- It has been revealed that investors have invested in PPF. So it can be suggested to the investors that they should continue with their PPF after maturity by extending it till their retirement to get maximum from the PPF as it after compounding interest and the whole amount received is tax exempted.

- Indian post office should provide a higher rate of interest on deposit it will lead to meet the competition.

- Indian post office should provide a ATM facility to the customers and provide information about how to using ATM facility to the customer.

- Indian post office should concentrate more towards advertising and promotional activities there by it helps to attract more customers.

- Indian post office should conduct customer awareness programme for both rural and urban area and also the post office should give better 
ISSN 2349-2325 (Online); DOI: 10.16962/EAPJFRM/issn. 2349-2325/2015; Volume 9 Issue 4 (2018)

customer care services and provide

the information about new scheme.

- It should provide good CONCLUSION

infrastructure facility to both rural and urban area to attract customers very easily.

- The post office should adopt Epostal system in both urban and rural areas to reduce the time as well as quick service to the customer.

- The post office should introduce commercial website for money transfer, bill deposit, E-payment etc.

- It should adopt modern technology to improve the quality of service to the customers.

- It should reduce transaction cost of some service like Speed post, Epost, Business post, etc. So that is very helpful to the middle and low class income group make use of the these services.

- It should provide the detail information about Sukanya Samrdhi Scheme because, there is not much awareness about this scheme and also provide some more scheme to the women.

- It should provide the awareness about the tax benefits to customer.

- Staff should cooperate with customers and should be given on customer relationship management.

Today postal department has to equip itself by improving its service and savings schemes to satisfy the customers. In the light of changing environment, it has to constantly upgrade its knowledge of the internal and external environment to understand the customer relationship properly. Savings is important for human life, as savings gives life and security. One of the main motives of the Department of Post is to uplift the savings of the people. Savings not only help the people, but help for the economic development.

The post office is universally recognized as a facilitator of communication. It has been backbone of the country's Socio-economic development. Post office has become a big business icon in the corporate world. It is dealing with a number of postal and financial services like E-post, E-billing, Retail post, Media post, mutual fund, Business post, Speed post, etc. The department of post also acts as agent for government of India in discharging other services citizens.

Today, safety of the investment is of utmost priority among people. One of the best 
ISSN 2349-2325 (Online); DOI: 10.16962/EAPJFRM/issn. 2349-2325/2015; Volume 9 Issue 4 (2018)

choices would be the post office. Since post

office is owned by the government of India, the money invested in it is $100 \%$ safe and secure. Post office saving is the best form of savings scheme which provides substantially higher rates of interest and pose relatively lesser risk of suffering losses.

The various small savings schemes are mainly meant to help the small investors and also those who are in high tax brackets. Proper advertisement must be made of the post office savings schemes, so that even a layman comes to know about these schemes and services and also deposit can be increased. Government should take proper steps to modify the existing procedures to improve small savings schemes ,then only Government can collect large amounts from rich and poor investors. Loan against various certificates and papers must be given to the investors directly in the post office where they hold the deposits. Investing our amount in post office deposits schemes ensure higher rate of return and it provides safety and security for the amount invested.

Indian postal services has to meet all postal needs for all section of people both rural and urban areas, individual, corporate organization and business firm and it should provide quality of service in excellent manner in future days also.

\section{LIST OF TABLES}

Table- 1: Analysis and Interpretation:

\begin{tabular}{|l|l|l|}
\hline Gender & $\begin{array}{l}\text { Number of } \\
\text { Respondents }\end{array}$ & $\begin{array}{l}\text { Percentages } \\
(\%)\end{array}$ \\
\hline Male & 52 & 52 \\
\hline Female & 48 & 48 \\
\hline Total & 100 & 100 \\
\hline Age Group & $\begin{array}{l}\text { Number of } \\
\text { Respondents }\end{array}$ & $\begin{array}{l}\text { Percentage } \\
(\%)\end{array}$ \\
\hline Below 20 & 12 & 12 \\
\hline years & 40 & 40 \\
\hline 41-60 years & 36 & 36 \\
\hline
\end{tabular}


ISSN 2349-2325 (Online); DOI: 10.16962/EAPJFRM/issn. 2349-2325/2015; Volume 9 Issue 4 (2018)

\begin{tabular}{|c|c|c|}
\hline $\begin{array}{ll}\text { Above } & 60 \\
\text { years } & \end{array}$ & 12 & 12 \\
\hline Total & 100 & 100 \\
\hline Occupation & $\begin{array}{l}\text { Number of } \\
\text { Respondents }\end{array}$ & $\begin{array}{l}\text { Percentages } \\
(\%)\end{array}$ \\
\hline Agriculturist & 32 & 32 \\
\hline Student & 24 & 24 \\
\hline $\begin{array}{l}\text { Government } \\
\text { employee }\end{array}$ & 10 & 10 \\
\hline $\begin{array}{l}\text { Private } \\
\text { employee }\end{array}$ & 16 & 16 \\
\hline Business man & 10 & 10 \\
\hline Other & 8 & 8 \\
\hline Total & 100 & 100 \\
\hline $\begin{array}{l}\text { Education } \\
\text { Qualificatio } \\
\text { n }\end{array}$ & $\begin{array}{l}\text { Number of } \\
\text { Respondents }\end{array}$ & $\begin{array}{l}\text { Percentages } \\
(\%)\end{array}$ \\
\hline SSLC & 36 & 36 \\
\hline PUC & 24 & 24 \\
\hline Graduation & 24 & 24 \\
\hline $\begin{array}{l}\text { Post } \\
\text { Graduation }\end{array}$ & 16 & 16 \\
\hline Total & 100 & 100 \\
\hline $\begin{array}{l}\text { Annual } \\
\text { Income }\end{array}$ & $\begin{array}{l}\text { Number of } \\
\text { Respondents }\end{array}$ & $\begin{array}{l}\text { Percentage } \\
(\%)\end{array}$ \\
\hline $\begin{array}{ll}\text { Less } & \text { than } \\
50000 & \end{array}$ & 40 & 40 \\
\hline $\begin{array}{l}50001- \\
100000\end{array}$ & 42 & 42 \\
\hline $\begin{array}{l}100001- \\
200000\end{array}$ & 12 & 12 \\
\hline $\begin{array}{l}200001 \\
\text { above }\end{array}$ & 6 & 6 \\
\hline
\end{tabular}




\begin{tabular}{|l|l|l|}
\hline Total & 100 & 100 \\
\hline
\end{tabular}

Table 2: Respondents investment in the saving scheme

\begin{tabular}{|l|l|l|l|}
\hline SI.No & Particulars & Number of Respondents & Percentage \\
\hline 1 & PORD & 42 & 42 \\
\hline 2 & SCSS & 16 & 16 \\
\hline 3 & MIS & 28 & 28 \\
\hline 4 & NSC/PPF & 14 & 14 \\
\hline \multicolumn{2}{|c|}{ Total } & 100 & 100 \\
\hline
\end{tabular}

Source: Field survey

Table 3:Reasons to prefer to post office savings scheme

\begin{tabular}{|l|l|l|l|}
\hline SI.No & Particulars & Number of Respondent & Percentage \\
\hline 1 & Attractive & 10 & 10 \\
\hline 2 & Savings & 60 & 60 \\
\hline 3 & Tax benefits & 22 & 22 \\
\hline 4 & Liquidity & 8 & 8 \\
\hline Total & 100 & 100 \\
\hline
\end{tabular}

Source: Field survey

Table 4: Rating of the services by the respondents.

\begin{tabular}{|l|l|l|l|l|l|l|l|l|l|l|}
\hline Particulars & \multicolumn{2}{l|}{ Excellent } & \multicolumn{2}{l|}{ Very good } & \multicolumn{2}{l|}{ Good } & \multicolumn{2}{l|}{ Average } & \multicolumn{2}{l|}{ Poor } \\
\hline & Res & $\%$ & Res & $\%$ & Res & $\%$ & Res & $\%$ & Res & $\%$ \\
\hline $\begin{array}{l}\text { Promptness of } \\
\text { services }\end{array}$ & 0 & 0 & 4 & 8 & 11 & 22 & 32 & 64 & 3 & 6 \\
\hline $\begin{array}{l}\text { Willingness to } \\
\text { offer help }\end{array}$ & 0 & 0 & 5 & 10 & 36 & 72 & 11 & 22 & 1 & 2 \\
\hline $\begin{array}{l}\text { Timely response } \\
\text { to request }\end{array}$ & 1 & 2 & 7 & 14 & 20 & 40 & 17 & 64 & 2 & 4 \\
\hline $\begin{array}{l}\text { Convenience of } \\
\text { operating hours }\end{array}$ & 0 & 0 & 4 & 8 & 26 & 52 & 16 & 32 & 3 & 6 \\
\hline
\end{tabular}


ISSN 2349-2325 (Online); DOI: 10.16962/EAPJFRM/issn. 2349-2325/2015; Volume 9 Issue 4 (2018)

\begin{tabular}{|l|l|l|l|l|l|l|l|l|l|l|}
\hline $\begin{array}{l}\text { Satisfaction with } \\
\text { postal } \\
\text { the }\end{array}$ & 1 & 2 & 17 & 34 & 24 & 48 & 6 & 12 & 2 & 4 \\
services
\end{tabular}

Source: Field survey

Table 5: Classification of the respondents on the basis of priority of different kind of nonpostal services

\begin{tabular}{|c|c|c|c|c|c|c|c|c|c|c|}
\hline \multirow[t]{2}{*}{ Particulars } & \multicolumn{2}{|c|}{ Excellent } & \multicolumn{2}{|c|}{ Very good } & \multicolumn{2}{|c|}{ Good } & \multicolumn{2}{|c|}{ Average } & \multicolumn{2}{|c|}{ Poor } \\
\hline & Res & $\%$ & Res & $\%$ & Res & $\%$ & Res & $\%$ & Res & $\%$ \\
\hline $\begin{array}{l}\text { Post office } \\
\text { monthly } \\
\text { income } \\
\text { scheme }\end{array}$ & 0 & 0 & 2 & 4 & 18 & 36 & 28 & 56 & 2 & 4 \\
\hline $\begin{array}{l}\text { Public } \\
\text { Provident fund }\end{array}$ & 0 & 0 & 1 & 2 & 22 & 44 & 18 & 36 & 9 & 18 \\
\hline $\begin{array}{l}\text { National } \\
\text { savings } \\
\text { certificate }\end{array}$ & 0 & 0 & 3 & 6 & 16 & 32 & 26 & 52 & 5 & 10 \\
\hline $\begin{array}{l}\text { Post office } \\
\text { saving account }\end{array}$ & 1 & 2 & 8 & 16 & 34 & 68 & 8 & 16 & 0 & 0 \\
\hline $\begin{array}{l}\text { Post office } \\
\text { Time Deposit }\end{array}$ & 1 & 2 & 15 & 30 & 24 & 48 & 8 & 16 & 2 & 4 \\
\hline $\begin{array}{l}\text { Senior Citizen } \\
\text { Savings } \\
\text { Scheme }\end{array}$ & 2 & 4 & 15 & 30 & 25 & 50 & 6 & 12 & 2 & 4 \\
\hline $\begin{array}{l}\text { Recurring } \\
\text { Deposit } \\
\text { Account }\end{array}$ & 1 & 2 & 9 & 18 & 34 & 68 & 6 & 12 & 0 & 0 \\
\hline
\end{tabular}

Sourse : Field survey

Table 6 : Awareness about the services in Respondents 
ISSN 2349-2325 (Online); DOI: 10.16962/EAPJFRM/issn. 2349-2325/2015; Volume 9 Issue 4 (2018)

\begin{tabular}{|c|c|c|c|c|c|c|}
\hline \multirow[t]{2}{*}{ SI.No } & \multirow[t]{2}{*}{ Particulars } & \multicolumn{2}{|l|}{ Yes } & \multicolumn{2}{|l|}{ No } & \multirow[t]{2}{*}{ Percentage } \\
\hline & & $\begin{array}{ll}\text { No. of } \\
\text { Res }\end{array}$ & $\%$ & $\begin{array}{l}\text { No. of } \\
\text { Res }\end{array}$ & $\%$ & \\
\hline 1 & Speed post & 46 & 92 & 4 & 8 & 100 \\
\hline 2 & Business post & 26 & 52 & 24 & 48 & 100 \\
\hline 3 & Media post & 11 & 22 & 39 & 78 & 100 \\
\hline 4 & Logistic post & 7 & 14 & 43 & 86 & 100 \\
\hline 5 & Direct post & 39 & 78 & 11 & 22 & 100 \\
\hline 6 & E-post & 32 & 64 & 18 & 36 & 100 \\
\hline
\end{tabular}

Source : Field survey

Table 7: Respondents of those who have invested in the Sukanya Sumrdhi Scheme

\begin{tabular}{|l|l|l|l|}
\hline SI.No & Particulars & Number of Responses & Percentage \\
\hline 1 & Yes & 40 & 40 \\
\hline 2 & No & 60 & 60 \\
\hline Total & 100 & 100 \\
\hline
\end{tabular}

Source : Field survey

Table 8 : Opinion of the respondents about privatization of post office

\begin{tabular}{|l|l|l|l|}
\hline $\begin{array}{l}\text { SI.N } \\
\text { o }\end{array}$ & Particulars & Number of Respondents & Percentage (\%) \\
\hline 1 & Yes & 18 & 18 \\
\hline 2 & No & 82 & 82 \\
\hline Total & 100 & 100 \\
\hline
\end{tabular}

Source : Field survey

Table- 9

H0:Customers are not satisfied with CRM provided by Post office

H1: Customers are satisfied with CRM provided by Post office

\begin{tabular}{|l|l|l|l|l|l|l|}
\hline Responses & Observed & Expected & $(\mathrm{O}-\mathrm{E})$ & $(\mathrm{O}-\mathrm{E})^{\wedge} 2$ & $(\mathrm{O}-\mathrm{E})^{\wedge} 2 / \mathrm{E}$ & Values \\
\hline Yes & 30 & 40 & -10 & 100 & $100 / 40$ & 2.5 \\
\hline
\end{tabular}


ELK ASIA PACIFIC JOURNAL OF FINANCE AND RISK MANAGEMENT

ISSN 2349-2325 (Online); DOI: 10.16962/EAPJFRM/issn. 2349-2325/2015; Volume 9 Issue 4 (2018)

\begin{tabular}{|l|l|l|l|l|l|l|}
\hline No & 70 & 60 & +10 & 100 & $100 / 60$ & 1.67 \\
\hline
\end{tabular}

Calculated Value $=\mathbf{4 . 1 7}$ 